\title{
The Relationship between Hand-Eye Coordination and Strength of Stomach Muscle on Clear Forehand Capability in Badminton Game on Student of Ciambar 1st Junior High School, Sukabumi District
}

\author{
Haerul Ikhsan* \\ Sport Education \\ Universitas Pendidikan Indonesia \\ Bandung, Indonesia \\ *haerulikhsan@upi.edu
}

\begin{abstract}
In this research purpose to know relation between coordination of eye-hand and the strength of stomach muscle to students in class VIII at SMPN 1 Ciambar have as background by role important coordination of eye-hand and the strength of stomach muscle in the badminton games. This research uses survey method with test technic and measuring population. In this research, the students in class VIII at SMPN 1 Ciambar who totally 284 students. Samples of research are one class, students in class VIII at SMPN 1 Ciambar who totally 28 students, with technic takes samples uses probability sampling. The instrument that used in this research namely: (1) test coordination of eyehand (2) test the strength of stomach muscle (3) test ability to hit clear forehand. Analysis technic data uses collecting data double correlation statistic technic are looking for the biggest relation and two free variable contribution $(X)$ or simultaneous (together) with bound variable (Y) to use double correlation, examine signification with Fcount. The result of research to shown that (1) there are relation which signification between coordination of eye hand (X1) and ability of blow clear forehand (Y). () there are which signification between the strength of stomach muscle (X2) and the strength of blow clear forehand (Y). (3) there are which signification between coordination of eye hand (X1) and the strength of stomach muscle (X2) to ability blow clear forehand (Y).
\end{abstract}

Keywords-coordination of eye-hand; the strength of stomach muscle; ability to blow clear forehand

\section{INTRODUCTION}

This research is focused on clear trawl technique, badminton game cannot be separated from the clear blow because often the opponent directs shuttlecock soared high above our heads so that requires us to make a clear forehand punch, clear blow itself is included as a special technique because this punch is difficult to do especially for player's beginners, because mechanically the forehand clear technique demands a perfect motion coordination. Forehand clear is a done high and long used to get more time to return to the position of the center of the field [1].
A clear forehand can be categorized as a difficult blow, because in biomechanics this punch technique in addition to demanding perfect limb coordination, also the mastery of the grip and timing must be appropriate. Without these three things, even great power will not produce a good punch quality. In making a clear forehand a good coordination of motion is needed, among which is having to master good eye and hand coordination so that a clear forehand blow can be done perfectly.

Hand-eye coordination is very important in a game, because in the game requires a variety of complex movements. Hand-eye coordination is a complex biometric capability that has a close relationship with speed, strength, durability and flexibility. At http://www.esortment.com, which was cited by Effendi that "the development of hand-eye coordination is criticizing in overall physical development". Eye and hand coordination are important in overall physical development. Skills in throwing, hitting, pushing, and attracting require eyehand coordination. Eye-hand coordination combines viewing ability and hand ability, for example in table tennis games before the eye-hitting movement must lead to the target or target object, while the hand serves to control the punch to match the target.

According to Bompa suggests that in eye and hand coordination will result in timing and accuracy [2]. Timing is oriented to timeliness, accuracy oriented towards target. Through good timing, the connection between the hand and the object will be in accordance with the desire so that it will produce an effective movement. Accuracy will determine whether or not the object to the intended target.

Based on some of the opinions mentioned above, it can be concluded that eye-hand coordination is a combination of eyes and hands to perform a movement, eyes to see height, magnitude, distance, target and hand to control the power that will be released so that effective movement is obtained on target. 
Strength is the power of muscle contraction that is achieved in a maximum effort. This maximum effort is done by a muscle or a group of muscles to overcome a prisoner. Strength is a very important element in sports activities, because strength is the driving force, and prevention of injury. Besides that, strength plays an important role in the components of other physical abilities such as power, agility, and speed [3]. The increase in strength is always followed by the size of the muscles getting bigger [4]. Based on the opinions of these expert's strength is a very important factor in sports activities.

\section{METHOD}

\section{A. Population and Sample}

1) Population: The population that the author uses in this study are all students of Ciambar 1 junior High School totaling 284 people.

2) Sample: In this study the author took a sample of eighth grade students totaling 28 people.

\section{B. Data Analysis}

Analysis of the data used in this study uses Double Correlation statistical data collection techniques, considering the data obtained is still in the form of raw data, it needs to be converted into standard data as follows:

1) Calculate the mean:

$$
\bar{X}=\frac{\Sigma x i}{n}
$$

2) Calculate the standard deviation:

$$
S^{2}=\sqrt{\frac{\sum\left(X_{1}-\bar{X}\right)^{2}}{n-1}}
$$

3) Find magnitude: After the raw data has been converted into standard data, the next step is to find the magnitude of the relationship and the contribution of two independent variables (X) or more simultaneously (together) with the dependent variable (Y) using the multiple correlation analysis technique.

$$
R_{X 1 X 2 Y}=\sqrt{\frac{r_{X ! Y}^{2}+r_{X 2 Y}^{2}-2\left(r_{X 1 Y}\right) \cdot\left(r_{X 2 Y}\right) \cdot\left(r_{X 1 X 2}\right)}{1-r_{X 1 X 2}^{2}}}
$$

\section{4) Significance test Fcount with:}

$$
F_{\text {count }}=\frac{\frac{R^{2}}{K}}{\frac{\left(1-r^{2}\right)}{n-k-1}}
$$

5) $r$ count by inputting statistics from the helper table with:

$$
r_{x 1 y}=\frac{n\left(\sum X_{I} y\right)-\left(\sum X_{I}\right) \cdot\left(\sum Y\right)}{\sqrt{\left\{n \cdot \sum X_{I}^{2}-\left(\sum X_{I}\right)^{2}\right\} \cdot\left\{n \cdot \sum Y^{2}-\left(\sum Y\right)^{2}\right\}}}
$$

6) Test the significance with:

$$
F_{\text {count }}=\frac{\frac{R^{2}}{K}}{\frac{\left(1-r^{2}\right)}{n-k-1}}
$$

If $\rightarrow$ Fcounts $\geq$ Ftable then reject $\mathrm{H} 0$ means that significance and Fcount $\leq$ Ftable accept $\mathrm{H} 0$ means that it is not significant. Find the Ftable value using table $\mathrm{F}$ with a significance level of $\alpha=0.05$. Ftable $=F\{(1-\alpha)(d k-k),(d k=$ $\mathrm{n}-\mathrm{k}-1)\}$. If $\rightarrow$ Fcounts $\geq$ Ftable then reject $\mathrm{H} 0$ means that significance and Fcount $\leq$ Ftable accept $\mathrm{HO}$ means that it is not significant. Find the Ftable value using table $F$ with a significance level of $\alpha=0.05$. Ftable $=F \quad\{(1-\alpha)(d k-k),(d k=$ $\mathrm{n}-\mathrm{k}-1)\}$.

\section{RESULTS}

Research activities that have been carried out once with data retrieval from the results of hand eye coordination test, stomach muscle strength test, and forehand clear blow test ability test then observe the results. Found a variety of physical conditions and abilities that there are students whose abilities are not increased caused due to illness factors, and delays when participating in learning badminton games at Ciambar 1 Junior High School.

During the research activities the students took the test seriously so that it increased after following the activity. In this discussion, the results of the study will be presented in the form of descriptive statistics for each variable, testing the requirements of multiple correlation analysis.

TABlE I. The Results of THE AVERAGE DATA CALCUlation AND STANDARD DEVIATION

\begin{tabular}{|l|l|l|}
\hline \multicolumn{1}{|c|}{ Source } & \multicolumn{1}{|c|}{ Average } & Standard deviation \\
\hline $\mathrm{X} 1$ & 9.82 & 3.02 \\
\hline $\mathrm{X} 2$ & 33.71 & 6.24 \\
\hline $\mathrm{Y}$ & 22.25 & 6.56 \\
\hline
\end{tabular}

TABLE II. THE RESUlTS OF THE CORRELATION BETWEEN HAND- EyE COORDINATION AND STOMUCH MUSCLE STRENGTH WITH THE ABILITY TO Clear Forehand

\begin{tabular}{|l|l|l|l|}
\hline Source & Average & Rcount & \multicolumn{2}{|c|}{ Conclusion } \\
\hline $\mathrm{X}_{1}$ & 9.82 & \multirow{2}{*}{0.798} & $\begin{array}{l}\text { Strong and hight } \\
\text { relationship level }\end{array}$ \\
\hline $\mathrm{X}_{2}$ & 33.71 & & \\
\hline $\mathrm{Y}$ & 22.25 & \\
\hline
\end{tabular}

The relationship between hand eye coordination and stomach muscle strength to the ability of clear forehand blows 
in badminton games on students of Ciambar 1 junior hight School is strong and high. Simultaneous construction R2 x $100 \%=0.7982 \times 100 \%=63.7 \%$ and the remaining $36.3 \%$ is determined by other variables.

TABLE III. SignifiCANCE TEST RESUlts Using F COUNT $_{\text {TI }}$

\begin{tabular}{|l|l|l|l|l|}
\hline Source & Average & Fcount & Ftabel & \multicolumn{1}{|c|}{ Conclusion } \\
\cline { 1 - 2 } $\mathrm{X} 1$ & 9.82 & 22,71 & 3.38 & $\begin{array}{l}\text { H0 rejected. } \\
\text { Ther are } \\
\text { significant } \\
\text { relationship }\end{array}$ \\
\hline $\mathrm{X} 2$ & 33.71 & 22.25 & & \\
\hline
\end{tabular}

Based on the results of table, correlation obtained Fcount (22.71)> Ftable (3.38) with a significance level of 0.05. By obtaining the results of the calculation of RX1X2Y of 0.798 with the category of strong and high. And stimulant construction R2 $\times 100 \%=0.7982 \times 100 \%=63.7 \%$ and the remaining $36.3 \%$. This means that mastery of eye hand coordination and stomach muscle strength contribute to the ability of clear forehand blows in badminton games by $63.7 \%$ and the remaining 36.3 by other variables.

\section{Discussion}

One component of the physical condition when making a clear forehand is hand-eye coordination, based on the results of hand-eye coordination research also provides a significant relationship with the results of a clear forehand blow on students of SMambar 1 Ciambar, which is equal to 0.677> Ftable 3.38. Thus it can be concluded that a clear forehand requires good hand eye coordination resulting in a blow that rises high and falls behind the opponent's field. It can be interpreted that the better the hand-eye coordination that a badminton player has, the better the results of the clear forehand will be performed. And on the contrary, the bad eye coordination of badminton players will be less good in the results of a clear forehand blow.

Stomach muscle strength also provides a significant relationship with the results of a clear forehand punch on students at SMPN 1 Ciambar, which is equal to 0.792> Ftable 3.38. Strength is the driving force, besides strength is the main factor to make a clear forehand blow optimally. Strength itself is used to change the state of motion or shape of an object. In a badminton game, the strength of a large stomach muscle will produce a good forehand blow that is directed and bounces high in the opponent's area, which can make it difficult for your opponent to receive a shuttlecock. Because the greater the strength of stomach muscles possessed by a badminton player, the greater the power produced when making a clear forehand punch so that the resulting blow will be good and directed.
Together the relationship of hand eye coordination and stomach muscle strength with the results of a clear forehand punch is strong and high that is equal to 0.798> Ftable 3.38. These results indicate that in addition to the physical condition elements there are other factors that influence the results of the clear forehand blow. Based on the results of calculations using multiple correlation technology obtained the results of Fcount (22.71)> Ftable (3.38) with a significance level of 0.05 then $\mathrm{H} 0$ is rejected, meaning that there is a correlation between hand eye coordination and stomach muscle strength against the ability of clear forehand in badminton in students of Ciambar 1 Junior High School.

\section{CONCLUSION}

Based on the results of data analysis and discussion, the conclusion of this study is:

- There is a significant relationship between hand eye coordination and the ability of clear forehand punches on students of Ciambar 1 Junior High School

- There is a significant relationship between stomach muscle strength and the ability of clear forehand blows in students of Ciambar 1 Junior High School.

- There is a significant relationship between hand eye coordination and stomach muscle strength on the ability of clear forehand blows in students at Ciambar 1 Junior High School.

Based on the results of the correlation of $\mathrm{X} 1, \mathrm{X} 2$ to $\mathrm{Y}$ obtained Fcount (22.71)> Ftable (3.38) with a significance level of 0.05 . By obtaining the results of the calculation of RX1X2Y of 0.798 with the category of strong and high. And stimulant construction R2 x 100\% $=0.7982 \times 100 \%=63.7 \%$ and the remaining $36.3 \%$. This means that mastery of eye hand coordination and stomach muscle strength contributes to the ability of clear forehand blows in badminton games by $63.7 \%$ and the remaining 36.3 by other variables.

\section{REFERENCES}

[1] T. Grice, Bulutangkis; Petunjuk Praktis untuk Pemula dan Lanjut. Jakarta, 2002.

[2] T.O. Bompa, Theory and methodology of training. Kendall/Hant: Iowa of University, 1994.

[3] B.D. Ismaryati, "Tes Dan Pengukuran Olahraga.," 2006.

[4] Nurhasan, Tes dan Pengukuran Pendidikan Olahraga. Bandung: Universitas Pendidikan Indonesia, 2000. 